\title{
Gender Influence on the Household Electrical Energy Consumption Behavior
}

\author{
Maria Isfus Senjawati ${ }^{1}$, Lusi Susanti ${ }^{2, *}$, ,Hilma Raimona Zadry $^{2}$, and Prima Fithri $^{2}$ \\ ${ }^{1}$ Polytechnic of ATI Padang, Industrial Ministry, Indonesia,Student at Department of Industrial \\ Engineering, Faculty of Engineering, Universitas Andalas, Padang, Indonesia \\ ${ }^{2}$ Department of Industrial Engineering, Faculty of Engineering, Universitas Andalas, Padang, Indonesia
}

\begin{abstract}
Increased energy consumption can lead to depletion of fossil energy reserves that can pose a threat to energy supply in Indonesia. One way to increase the intensity of energy savings is to make changes in consumer behavior. The development of gender roles, abilities, and attention led most researchers to argue that women are more consistent in attention to environmental change than men. Women are more concerned with environmental quality and participate in environmental activities. Thus, this research tries to determine the influence of psychological factors on the behavior of household electrical energy consumption in term of gender differences. This study used questionnaires distributed using Google Docs to household electrical respondents several in Indonesia. Referring to ABC (Antecedents-Behaviour-Consequences) model of consumer behavior, the total of 808, questionnaires from 526 male respondents and 282 female respondents were successfully collected. The data were processed by the Partial Least Square Equation Modeling Model (SEM-PLS) using SmartPLS software. The study concluded that,if given the consequences, women have higher influence to the behavior of electrical energy consumption than men.Overall psychological factors have a positive and significant influence on the behavior of electric energy consumption in Indonesia.
\end{abstract}

\section{Introduction}

One source of energy that still dominates the final energy consumption in various sectors is electrical energy. In 2013 and 2016, the national electricity demand is 190 Tera Watt Hour (TWh) and $232 \mathrm{TWh}$, respectively, with the household sector in both years is still dominating with a share of more than $41 \%$, the highest among other consumer sectors such as industry $(34 \%)$, followed by the commercial sector $(24 \%)$, and transportation sector $(0.1 \%)$ [1].

One way to increase the intensity of energy savings is to make changes in consumer behavior. Rani [2] states that consumer behavior is influenced by four main factors namely cultural, social, personal and psychological. Wijaya and Tezuka [3] states that one of the most significant efforts in encouraging people to behave in energy-efficient ways is to build energy-saving awareness.

\footnotetext{
*Corresponding author: lusi@eng.unand.ac.id
} 
Research on energyawareness have been conducted by some previous studies i.e. study byWai [4], [11] which developed a conceptual model about building awareness of energy saving and study by Maag [5] which developed a Three Term Contingency model or also known as ABC (Antecedents-Behavior-Consequences). The model can be used to describe how to manage behavior and awarenessof energy saving. Study by Frederiks et al. [6], states that consumer behavior in terms of energy consumption is influenced by socio-demographic factors (gender, age, educational level, occupation and so on) and psychological factors (individual personality values, awareness, etc.) Psychological factors, especially social values for household energy needs together with personal values will result in a different awareness of energy consumption with different motivations [7]. Fithri et al. [8] also stated that gender influenced the behavior of electrical energy consumption. This study is conducted as an attempt to determine the effect of psychological factors on the behavior of household electrical energy consumption seen from gender differences.

\section{Methods}

\subsection{Respondents}

Respondents involved in this study were 808 household electrical energy consumers in Indonesia. The respondents consist of 526 men and 282 women from some of Java and Sumatra provinces.

\subsection{Questionnaire Design}

This research instrument used questionnaires which developed using data of information and behavior of household electrical energy consumption compiled from several literatures [7,9]. The questionnaires were filled online by respondents using google docs application which contains a list of questions or statements as follows:

a. Preface, contains the purpose of data collection, its benefits, and the main topic of this research.

b. The first part, contains a general information and socio-demographic data of respondents as documentation of the research.

c. The second part, contains the statements to obtain information about the psychological factors (45 statements), electrical energy saving behavior (17 statements), and the regulation factorsof electrical energy saving behavior ( 5 statements).

d. The third part, contains the amount and length of time the household electrical appliances are used.

\subsection{Indicators and variables laten/construct}

Table 1. Energy Saving Behavior Questionnaire Indicators Viewed from Psychological Factors.

\begin{tabular}{|l|l|l|}
\hline \multicolumn{1}{|c|}{ Variabel } & \multicolumn{1}{|c|}{ Indicator } & Total \\
\hline Values, Norms and Individual Personality (n) & $\begin{array}{l}\mathrm{n} 1, \mathrm{n} 2, \mathrm{n} 3, \mathrm{n} 4, \mathrm{n} 5, \mathrm{n} 6, \mathrm{n} 7, \ldots . ., \\
\mathrm{n} 36\end{array}$ & 36 \\
\hline Level of Awareness of Energy Problems (k) & $\mathrm{k} 1, \mathrm{k} 2, \mathrm{k} 3, \mathrm{k} 4, \mathrm{k} 5, \mathrm{k} 6, \mathrm{k} 7, \mathrm{k} 8, \mathrm{k} 9$ & 9 \\
\hline Behavior of Electrical Energy consumption(p) & $\mathrm{p} 1, \mathrm{p} 2, \mathrm{p} 3, \mathrm{p} 4, \mathrm{p} 5, \mathrm{p} 6, \mathrm{p} 7, ., \mathrm{p} 17$ & 17 \\
\hline Regulation Factors (r) & $\mathrm{r} 1, \mathrm{r} 2, \mathrm{r} 3, \mathrm{r} 4, \mathrm{r} 5$ & 5 \\
\hline
\end{tabular}




\subsection{Data collection and analysis}

The number of respondents obtained is 808 respondents with the description in Table 1 .

Table 2 Recapitulation of Respondents

\begin{tabular}{|c|l|c|c|c|}
\hline NO & Region & Male & Female & Amount \\
\hline $\mathbf{1}$ & Java & 276 & 132 & 408 \\
\hline $\mathbf{2}$ & Sumatra & 250 & 150 & 400 \\
\hline \multicolumn{2}{|l}{ TOTAL } & 526 & 282 & 808 \\
\hline
\end{tabular}

\subsubsection{Outer Model (Measurement Model), the test is as follows:}

A. ValidityTest

1) Convergent validity

Convergent validity test used to measure the internal positive correlation of the construct variable. Correlation value is valid if greater than 0.70 . However, for early research stage , the values between 0.50 to 0.60 is considered sufficient [10]. After the re-estimation of 3 times, the value of outer loading on the data of women and men is already worth bigger than 0.5 . Valid indicator data on psychological factors male is 23 , behavior is 15 , and regulation factorsis 5 . While the female gender indicator valid on psychological factors is 25 , behavior is 14 , and regulation factorsis 5 . Thus, convergent validity of factors psychological, regulation factorsand behavior are valid.

2) Discriminant validity

Discriminant validity is the unique test of each construct of a measurement model. This is done by comparing the loading constructs measured by loading other constructs. The overall constructs meet the criteria of discriminant validity, in which all constructs predict their indicators are greater than other indicators.

B. Reliability Test

Composite reliability (CR) is worth between 0 to 1 , the higher the value of Cronbach's alpha indicates the higher level of reliability of the measurement model. Variables have good reliability when CR value is greater than 0.7 and Cronbach's Alpha value is greater than 0.6 [10]. After testing for reliability measurement, the construct used in this model is acceptable and reliable in hypothesis testing.

\subsubsection{Inner Model Evaluation (Evaluation of Structural Model)}

The next step is to evaluate the structural model by looking at the path coefficient on the PLS output. Path coefficient obtained after bootstrapping on Smart-PLS software. The structural model evaluation can be seen in the original sample $(\mathrm{O})$ contained in the output path coefficient. If the original sample is positive $(+)$ then there is a positive correlation relationship, and vice versa if the original sample is negative (-) then indicates a negative linkage relationship. Inner model analysis can also be seen from the acquisition of R-Square on PLS output. R-Square is useful for viewing variable abilities in percentage form. The higher the R-Square value indicates a good model. The original values of the sample and RSquare can be seen in Table 2 and Table 3.

Table 3 Original Sample Value

\begin{tabular}{|l|c|c|}
\hline \multirow{2}{*}{} & Male & Female \\
\cline { 2 - 3 } & \multicolumn{2}{|c|}{ Original Sample (O) } \\
\hline Regulation factors-> Behavior & 0.545 & 0.583 \\
\hline Psychological-> Behavior & 0.293 & 0.213 \\
\hline
\end{tabular}


Table. 3 shows that psychological variables and order/positive relationships to behavior (behavior). Women can calculate factors that lead to higher behavior than men. For psychological factors men who have psychological factor value to be higher than women.

Table 4 R-Square Value

\begin{tabular}{|l|c|c|}
\hline \multirow{2}{*}{ Behavior } & Male & Female \\
\cline { 2 - 3 } & \multicolumn{2}{|c|}{ R-Square } \\
\hline
\end{tabular}

Table. 4shows that the factors and psychology can explain the effect for women by $46.3 \%$ and men by $50.7 \%$ against behavioral variables. So the factors that influence the electrical behavior of household electricity, men provide a greater role than women.

\subsection{Analysis}

Table 5 T-statistics and p-value

\begin{tabular}{|l|c|c|c|c|}
\hline \multirow{2}{*}{} & \multicolumn{2}{|c|}{ Male } & \multicolumn{2}{c|}{ Female } \\
\cline { 2 - 5 } & T Statistics & P Values & T Statistics & P Values \\
\hline Regulation factors-> Behavior & 15.282 & 0 & 12.136 & 0 \\
\hline Psychological -> Behavior & 7.966 & 0 & 4.5170 & 0 \\
\hline
\end{tabular}

Table 5 shows a variety of behavioral, psychological factors having a greater t-statistic than women, a small p-value of 0.05 ; some elements have greater statistical t-statistics than women with a low p-value of 0,05 . Then it can be concluded that psychological variables give a positive influence on these variables, and male psychological factors are more dominant than women.

\section{Conclusion}

Psychological factor and the regulation factorson male gender can explain the effect of $50.7 \%$ on behavioral variables whereas in the female gender can explain the effect of $46.3 \%$ to behavioral variables behavior. This study concludes that psychological factors have a significant and positive influence on household electrical energy consumption behavior in terms of gender differences, where men have more influential to psychological factors than women do. The study suggest that (1) The government needs to make of energy conservation policy especially electrical energy with psychological factor approach such as communicative message and strong intervention and right target on the household electrical energy consumption behavior (2) Future study can investigate more psychological factors in other sectorson energy saving awareness behavior of household sector electricity.

This study is partly funded by Ristek-Dikti through PDUPT Grant No. 02/UN.16.17/PP.PDUPT.EET/ $\mathrm{LPPM} / 2018$.

\section{References}

1. BPPT. Indonesia Energy Outlook 2015. Journal of Chemical Information and Modeling (Vol. 53). https://doi.org/10.1017/CBO9781107415324.004. (2015)

2. Rani, P. Factors Influencing Consumer Behavior. International Journal of Review Research and Academic Review. Vol.2(9): 52-61. (2014).

3. Wijaya, M. E., and Tezuka, T. Policy-Making for Households Appliances-Related 
Electricity Consumption in Indonesia A-Multicultural Country. Open Journal of Energy Efficiency, 2013(June), 53-64. https://doi.org/10.4236/ojee.2013.22009 (2013).

4. Wai, C. W. Energy Conservation: A Conceptual Framework of Energy Awareness Development Process. 3rd International Conference on Energy and Environment, 74(April 2006), 306-313. (2009).

5. Maag, J. W. Behavior Management: From Theoretical Implication to Practical applications. Belmont, CA: Thomson/Wadsworth. (2004).

6. Frederiks, E. R., Stenner, K., and Hobman, E. V. The socio-demographic and psychological predictors of residential energy consumption: A comprehensive review. Energies, 8(1), 573-609. https://doi.org/10.3390/en8010573 (2015).

7. Vringer, K., Aalbers, T., and Blok, K. Household energy requirement and value patterns 1, 1 553-566. (2007).

8. Fithri, P., Susanti, L., and Bestarina, K. Assessing Household Energy Savings and Consumer Behavior in Padang City. Proceedings of the International Multi Conference of Engineers and Computer Scientists, 2(March), 18-22. (2014).

9. Rohana. Analisis Perilaku Pelanggan PLN dalam Pemakaian Daya Listrik Studi pada PT PLN (PERSERO) Wilayah Sumatera Utara Cabang Medan. Tesis Master. Universitas Sumatera Utara, Medan. (2008).

10. Ghozali, I Model Persamaan Struktural Konsep dan Aplikasi dengan Program Amos 16.0, Badan Penerbit UNDIP, Semarang. (2008).

11. Iwan, S., Hiroshi, M., \& Lusi, S. Household lifestyle effect on residential electrical energy consumption in Indonesia: On-site measurement methods. Urban Climate, 20, 20-30. (2017). 